\title{
The Contradiction between Macro-liquidity and Internal Liquidity of the Corporates and Their Corresponding Early-warning System
}

\author{
Linan Wang \\ Jilin University of Finance and economics \\ JLUFE \\ Changchun, China \\ 81212308@qq.com
}

\author{
Xin Jin \\ Jilin University of Finance and economics \\ JLUFE \\ Changchun, China \\ 2270443542@qq.com
}

\author{
Jingrong Li \\ Jilin University of Finance and economics \\ JLUFE \\ Changchun, China \\ 1508883250@qq.com
}

\begin{abstract}
Recent years, there have always existing a deviation of micro- liquidity from macro-liquidity in our country. Central bank insists on a prudent monetary policy with some flexibility. M2 continues to rise, meaning there is sufficient liquidity at the macro level. On the contrary, at the micro level, a considerable number of corporates still withstand the tight internal liquidity environment. Directed to this contradiction, in view of this contradiction, this article has put forward some suggestions from the macroscopic level and the enterprise angle and paid more attention to the viewpoint of the enterprise at the same time. To begin with, companies can use inversion ideas to establish a financing risks early warning system based on liquidity constraints. Then, based on the previous warning system, this paper constructs a liquidity constraints and the enterprise debt financing timing selection model, which provides a reference for enterprises to choose the optimal timing of debt financing in the current situation. ${ }^{[1]}$
\end{abstract}

Keywords-macro liquidity constraint; micro liquidity constraint; debt financing timing choice

\section{INTRODUCTION}

Debt financing is an important financing channel for corporates. And even for most enterprises, debt financing is the major source of funds. Compared with the debt funds, the proportion of equity financing is very low.

Recent years, China has always insisted on implementing a prudent monetary policy with some flexibility. The M2, or broad money supply, continues to rise, which means a sufficient liquidity at the macro level. On the contrary, at the micro level, a considerable number of corporates still withstand the tight internal liquidity environment and the low asset liquidity.

Due to the lack of liquid assets which conducted as

This paper is the periodical achievement of the Jilin University of Finance and Economics (2016B11), and is supported by the strategic management accounting research center of the Accounting School of Jilin University of Finance and economics. necessary collaterals, external financing is difficult and the external financing costs of enterprises is too high, resulting in debt financing constraints. Lack of liquidity of the company itself can't provide enough internal funds and face the debt financing constraints, which means that it is not only difficult to obtain sufficient subsidies and support for foreign capital financing, but also will bring some troubles such as the failure to optimize investment and low production efficiency, hindering the normal operation and long-term development of the company eventually. Reasons to the phenomena mentioned above are complex, which are mainly due to capital-intensive industries such as real estate and mineral metallurgy as well as the local government financing platforms for infrastructure construction occupying an enormous sum of money. Although there exists issues such as overcapacity and outdated capacity in these industries, they are still heavily in debt, which wastes a large number of social monetary fund supplies, resulting in inefficient allocation of funds, ultimately causing the effective rate of interest in capital market being in a dilemma that easy to rise but difficult to decline. ${ }^{[2]}$

This paper will focus on the contradiction our country being confronted with at the present stage that the microenvironment of liquidity deviating from liquidity surroundings on the macro-level, starting from the preceding industries, exploring the uncovered reasons according with economic logic on its high financial leverage. The article will also have a series of further discussion on the formation process of the contradiction that companies' high debt leverage-heavy capital costs which corporates have to burden- inadequate social money supply- deviation of the micro liquidity environment from the macro ones and construct a framework on analyzing the impact of liquidity constraints on corporate debt financing. Different enterprises are confronted with varying degrees of 
liquidity constraints caused by the situation of the tightening financing constraints, which brings about enterprise certain degrees of idiosyncratic risks, aggravating corporates' operational risks and financing risks in the end. This paper will also discuss from both the macro and micro point of views, analyzing the of methods of cutting down the social financial leverage, and particularly propose some welldirected suggestions on the high risk of debt financing from the companies' point of views. For one thing, our study borrows from the inversion prediction method, by observing the relevant information of the highly indebted companies which are influenced by the liquidity constraints, to deduce the formation mechanism of the high debt condition, so as to establish an early-warning model focusing on the extent of feature parameters which could avoid hazards from debt financing by research corporates financing behaviors. For another, by studying the influence of the increasing liquidity constraints on the timing choice of corporate debt financing, the paper constructs the theoretical model of the relationship on liquidity constraints and enterprise debt financing timing choices, aiming at providing a reference for determination on loan for decision-making as well as choosing a best method of debt financing.

\section{The Current Situation On DeViation of Micro-} LIQUIDITY FROM MACROSCOPIC LIQUIDITY AND THE CAUSES

\section{A. The current situation on deviation of microliquidity from macroscopic liquidity}

Recent years, China has appeared the contradiction scene that micro liquidity situation deviates from macro-ecomomic environment. On one hand, macroscopic liquidity is abundant. China has always insisted on a prudent monetary policy with some flexibility, and the monetary supply index M2 continues to rise, demonstrating money supply has always being adequate. On the other hand, in loan markets, money shortage has emerged, which induce debt shortage status, with the dilemma that real interest rates are easy to rise but difficult to go down. As a result, capital costs faced by the most companies remain high. Additionally, it is difficult for companies to obtain enough external financing from the loan markets, resulting in theirs tight internal liquidity environment and environmental tensions and insufficient liquidity of assets, which severely constrain the daily operations and development of enterprises.

\section{B. Analysis on causes of the situation on deviation of micro- liquidity from macro-liquidity}

In the framework of Keynes' classic analysis on money supply and demand, the liquidity demand of the commercial banking system is a function of interest rate. The central bank, being the only source of liquidity, supplies exogenously macro-liquidity, and the equilibrium interest rate is determined by the balance of money supply and demand. The reason why China's micro liquidity constraints deviate from the macro view is that in the case of continuous increase in the supply of money, it is only when the demand of the currency has increased substantially, that the equilibrium interest rate will be easy to rise but difficult to go down. However, most enterprises still have difficulty in either obtaining loans from the lending market, or shouldering excessively high costs of financing. Conducting a research on the basis of Chinese actual economic situation, one might discover that, there exists a severe mismatch phenomenon of the social capital. For example, although the real estate industry has problems of excessive inventory, it has a high financial leverage yet, which means a poor efficiency of utilization of the funds. Same are the cases with some industries such as steel industry or mineral industry, which already need elimination of theirs backward and excessive production capacity. Capital intensive industries still waste a lot of money supply. Moreover, local government financing platforms for infrastructure construction also occupy a large amount of money, with a high-level leverage, which might be of potential for systemic risks. Overall, owing to the above-mentioned capital mismatch phenomena, the allocation of social funds is inefficient. There are many causes explaining for this constriction. For one thing, the main reason is our particularly national conditions on public ownership economic system. Enterprises with public ownership can always get more resources depending on their specific ownership, for example, state-owned firms could have an easier access to the loans due to the alike ownership of the commercial banks, even though they are facing severe problems on outdated as well as excess production capacity. Consequently, the allocation of social money is bound to inefficient. For another, the hidden cause is the prevalence of the commercial banks' off-balance sheet business, so that a large amount of money could escape from the supervision of the central bank to the industries which are regulated by country's economic policy such as real estate industry and the local government financing platform for infrastructure construction due to the high profits, affecting the implementing of national macro-control policies.

From the preceding analysis, it is inferred that the financing environment of the liquidity constraints faced by firms in our country is logically summed up as a series of mutual influence process: "high debt leverage of the country - high cost of capital - money shortage, loan shortage - deviation of macroeconomic environment and micro-economic environment tight corporate debt environment ", which ultimately brings to enterprises high financial leverage and the high cost restricts the daily operation and development of enterprises.

\section{MEAsures of the Situation On Deviation OF Micro- LIQUIDITY FROM MACRO-LIQUIDITY}

In order to solve the problem that micro-liquidity constraints deviating from macro liquidity environment the Chinese enterprises being confronted with, our government should take corresponding macro measures to solve the problem of high financial cost and high financial leverage in the whole society. As the main body of micro-economic activities, the micro-enterprises should actively take measures to turn their passive attitude to a active participation to improve their own financing environment and better safeguard their own maximized benefits. 


\section{A. Macro-measures of the situation on deviation of micro-} liquidity from macroscopic liquidity

The government should continue to deepen the implementing of structural reform on the supply side. To begin with, on the aspect of the production capacity, the government should insist on the regulation on operation of the iron, steel and coal industry to resolve excess production, eliminate backward production capacity, properly disposing the "zombie enterprises" and persisting on carrying out the policy such as closing down, suspending operation, merging with others or shifting to different line of production and turning to reduce its large amount of inefficient occupation of funds. Secondly, on the aspect of reducing inventory in real estate industry, we must adhere to the regulations according to different locations and cities, focusing on solving the problems that three or four tier cities have excess inventory in real estate industry. It is necessary to combine the reducing inventory and promoting the rural population migrate to cities, upgrade the urban infrastructure and public service in the three or four tier cities, and enhance its attraction to the agricultural population. Last but not least, on the aspect of regulating the government's lending behavior, we will focus on local government financing platforms that serve local infrastructure, and regulate their operations to prevent the outbreaks of systemic risks. At the same time, more attention should be paid to strengthen the "shadow banking", namely commercial bank's off-balance sheet business regulation, to prevent a large amount of bank funds bypass the regular surveillance system, and flow into the above-mentioned profitable industries which are regulated by macro-economic policies, ensuring the implementation of the supply side structural reform regulation policy effect. ${ }^{[3]}$

\section{B. Measures of the situation on deviation of micro- liquidity from macroscopic liquidity from the view of corporates}

Although the major participants in microeconomic activities are surrounded by the tense liquidity environment, enterprises can only passively accept the status quo. However, appropriate measures should be taken in time to maximize their own financing environment and their own interests.

Enterprises can use reverse thinking to establish financing risk early warning system based on liquidity constraints. On the basis of model knowledge, inversion takes full advantage of all the prior knowledge, establishes the knowledge warehouse, and estimates the state parameters of the target based on the measurable parameter value. In practice, due to the increase of liquidity constraints, it is necessary to observe the relevant information of highly indebted enterprises which are affected by liquidity constraints, so as to estimate what characteristic parameters will lead to enterprise financing risks in corporate debt financing, deduce the mechanisms that high debt process occurs, and explore the moral hazard and the lack of debt constraint mechanism behind the enterprise high debt.

Based on the financing risk warning system of liquidity constraints, the enterprise can establish liquidity constraints and corporate debt financing timing model, provide a reference for enterprises to choose the optimal debt financing opportunity in the current situation. Specifically, from the perspective of the existing corporate debt financing market timing theory, the liquidity constraint is incorporated into the corporate debt financing timing. We can discuss the liquidity constraints of corporate debt financing costs, financial flexibility, management decision psychology, financing risk and uncertainty, mergers and acquisitions, competition and capital market financing conditions from many aspects. Then, we can introduce the liquidity constraint impact into the existing theory of debt financing, establish a new "liquidity constraints - enterprise debt financing timing" model, and test. Finally, by empirical methods, the key factors affecting the liquidity constraint choice of the corporate debt financing market are analyzed in time series and characteristics to determine the best financing average and the reasonable effect of debt financing enterprises. ${ }^{[4]}$

\section{CONCLUSION}

In order to solve the problem of liquidity constraint for Chinese enterprises, from the macro and micro financing environment, the state should take corresponding measures to solve the problem of macro level, high cost of social capital and high leverage ratio. As the micro subject of economic activities, enterprises should take active measures to change the passive into initiative, improve their own financing environment to the greatest extent, and better safeguard their own interests.

\section{REFERENCES}

[1] Bruce Greenwald. Informational Imperfections in the Capital Market and Macroeconomic Fluctuations Informational Imperfections in the Capital Market and Macroeconomic Fluctuations[J].The American Economic Review.1984,Vol.74(No.2):194-199.

[2] STEWART C. MYERS. The Capital Structure Puzzle[J].The Journal of Finance.1984,Vol.39(No.3):574-592.

[3] Steven M. Fazzari; R. Glenn Hubbard; Bruce C. Petersen; Alan S. Blinder; James M. Poterba. Financing Constraints and Corporate Investment[J].Brookings Papers on Economic Activity. 1988, Vol.19 (No.1):141-206.

[4] Toni M. Whited. Debt, Liquidity Constraints, and Corporate Investment: Evidence from Panel Data[J].The Journal of Finance. 1992, Vol.47 (No.4):1425-146 